\title{
Candida albicans aspartic proteinase cleaves and inactivates human epidermal cysteine proteinase inhibitor, cystatin A
}

\author{
Hirofumi Tsushima, ${ }^{1}+$ Hiroko Mine, ${ }^{2}$ Yasuhiko Kawakami, ${ }^{1}$ \\ Fuminori Hyodoh ${ }^{1}$ and Ayako Ueki ${ }^{1}$
}

Author for correspondence: Hirofumi Tsushima. Tel: +81 824522116 . Fax: +81824523731.

\footnotetext{
1 Department of Hygiene, Kawasaki Medical School, 577 Matsushima, Kurashiki, 701-01, Japan

2 Department of Clinical Nutrition, Kawasaki University of Medical Welfare, 288 Matsushima, Kurashiki, 701-01, Japan
}

\begin{abstract}
It is known that the cysteine proteinase inhibitor, cystatin, has a defence function against exogenous pathogens. Human epidermal cysteine proteinase inhibitor, cystatin A, which is a member of the cystatin family, is localized in the upper epidermal layer. In this study, the relationship between cystatin A and Candida aspartic proteinase (CAP), a putative Candida virulence factor, was studied. CAP activity was not affected by human epidermal cystatin A, while $90 \%$ of cystatin A activity was lost after incubation with CAP for $12 \mathrm{~h}$ at $37^{\circ} \mathrm{C}$. Human epidermal cystatin A was cleaved into small peptides by CAP, and the released peptides had no cystatin activity. These results suggest that CAP may induce an imbalance between cysteine proteinase and its inhibitor in cutaneous Candida infectious lesions through the degradation and inactivation of epidermal cystatin A.
\end{abstract}

Keywords: Candida albicans, aspartic proteinase, virulence factor, cystatin A

\section{INTRODUCTION}

Cysteine proteinase inhibitors have been found in many human tissues and fluids (Barrett $e t$ al., 1986). The cystatin superfamily of cysteine proteinase inhibitors was defined on the basis of similarities in primary structure (Barrett $e t$ al., 1986); it comprises three families, 1-3. The cystatins are known to have a regulatory role in intracellular protein catabolism (Katunuma, 1989). They also act as antiviral and/or antibacterial agents (Korant et al., 1985; Björck et al., 1989, 1990). The maintenance of homeostasis and defence against exogenous pathogens are assumed to be the main physiological functions of cystatins. Human epidermal cysteine proteinase inhibitor, cystatin $\mathrm{A}$, is a member of cystatin family 1 (Barrett et al., 1983). The human epidermis, especially the upper epidermal layer, contains an abundance of cystatin A (Hopsu-Havu et al., 1983).

Candida albicans is a common pathogenic fungus in skin infections (Ahearn, 1978), and an aspartic proteinase excreted by this organism ( $C$. albicans aspartic proteinase: CAP) is a putative virulence factor (Germaine et al., 1978;

\footnotetext{
Present address: Laboratory for Medical Biology Tsushima Clinic, 4830-1 Shikina, Miwa-cho, Futami-gun, Hiroshima-ken, 729-67, Japan.

Abbreviations: CAP, Candida aspartic proteinase; BANA, $\alpha-N$-benzoyl-DLarginine $\beta$-naphthylamide; CM, carboxymethyl; TFA, trifluoroacetic acid.
}

Rüchel, 1981; MacDonald \& Odds, 1983; Odds, 1985; Rüchel et al., 1985; Remold et al., 1968; Kwon-Chung et al., 1985; Ghannoum \& Elteen, 1986; Borg \& Rüchel, 1988). It has already been reported that CAP can degrade various extracellular proteins, such as keratin (Hattori et al., 1981), collagen (Kaminishi et al., 1986, 1988), immunoglobulins (Rüchel, 1986), and albumin, laminin and fibronectin (Ray \& Payne, 1991).

It was unknown whether CAP can degrade and inactivate epidermal cystatin A. In this study, we showed that CAP can degrade and inactivate human epidermal cystatin $A$. We also determined the cleavage sites of cystatin $A$ by CAP.

\section{METHODS}

Materials. Bovine serum albumin, bovine haemoglobin, papain, phenylmethylsulfonyl fluoride and $\alpha$ - $N$-benzoyl-DL-arginine $\beta$ naphthylamide (BANA) were purchased from Sigma. Pepstatin A was obtained from the Peptide Institute (Osaka, Japan). DEAE-Sephacel was from Pharmacia and DE-52 was from Whatman Biosystems. Carboxymethyl (CM)-papain Sepharose affinity chromatography was done according to the method of Anastasi $e t$ al. (1983). The reverse-phase HPLC column was a Bondasphere S-5 C18 (Nihon Waters). All other chemicals used were of analytical grade.

Organism. C. albicans IFO 1060 was maintained on Sabouraud glucose agar at room temperature. 
Culture of C. albicans. The growth medium used contained $12.0 \mathrm{~g}$ yeast carbon base and $2.0 \mathrm{~g}$ bovine serum albumin in 1 litre of distilled water. The medium was sterilized by filtration and then C. albicans was inoculated into a $50 \mathrm{ml}$ aliquot of medium. When the $\mathrm{pH}$ had reached near 3.0 after $7 \mathrm{~d}$, culture was stopped. Four hundred millilitres of $7 \mathrm{~d}$ culture medium were centrifuged at $4000 \mathrm{~g}$ for $30 \mathrm{~min}$ to remove cells. This supernatant was used as the starting material for purification of CAP.

Purification of CAP. The collected culture medium was lyophilized before purification of the proteinase. The lyophilized material was solubilized with $10 \mathrm{mM}$ sodium citrate buffer ( $\mathrm{pH} 6.7$ ), and then dialysed against the same buffer. The dialysed sample $(20 \mathrm{ml})$ was applied to a DEAE-Sephacel column $(2.5 \times 4.5 \mathrm{~cm})$, and the adsorbed proteins were eluted with a linear gradient of $10-400 \mathrm{mM}$ sodium citrate buffer $(\mathrm{pH} \mathrm{6.7)}$ ) as described by Kaminishi et al. (1986). The active fractions were collected, dialysed against distilled water, and then lyophilized. The purity of the enzyme was confirmed by SDS-PAGE.

Purification of human epidermal cystatin A. The purification method described previously (Tsushima et al., 1992) was used. Human epidermal cystatin A was obtained from human stratum corneum cells, collected by scraping the heels of healthy males. The skin scrapings $(6.7 \mathrm{~g})$ were homogenized with a glass homogenizer in $67 \mathrm{ml} 0.01 \mathrm{M}$ Tris/ $\mathrm{HCl}$ buffer $(\mathrm{pH} 8.0)$ and extracted overnight at $4{ }^{\circ} \mathrm{C}$. After centrifugation at $30000 \mathrm{~g}$ for $30 \mathrm{~min}$, the supernatant thus obtained was used as the starting sample for cystatin A purification. The sample was run through a DE-52 ion-exchange column $(1.5 \times 5.7 \mathrm{~cm})$ equilibrated with $0.01 \mathrm{M}$ Tris/HCl buffer $(\mathrm{pH} 8 \cdot 0)$. The active fractions were eluted with a linear gradient of $0-0 \cdot 3 \mathrm{M} \mathrm{NaCl} / 0 \cdot 01 \mathrm{M}$ Tris/HCl buffer $(\mathrm{pH} 8 \cdot 0)$. They were collected and dialysed against $0.01 \mathrm{M}$ Tris/ $\mathrm{HCl}$ buffer $(\mathrm{pH} 8 \cdot 0)$, then applied to a CM-papain affinity column $(2.5 \times 4.0 \mathrm{~cm})$ that had been equilibrated with the same buffer. The adsorbed active fractions were eluted with $5 \mathrm{mM} \mathrm{NaOH}$, collected, neutralized, and then dialysed against distilled water. The purity of the cystatin A thus obtained was confirmed by SDS-PAGE.

Assay of proteinase activity, proteinase inhibitory activity, and protein concentration. CAP activity was determined with $1.25 \%(\mathrm{w} / \mathrm{v})$ bovine haemoglobin as the substrate by a modification of the method of Anson (1938). The reaction mixture contained $0.2 \mathrm{ml} 0 \cdot 1 \mathrm{M}$ sodium acetate buffer $(\mathrm{pH} \mathrm{3.8)}$, $0.2 \mathrm{ml}$ buffered haemoglobin solution, and $0.1 \mathrm{ml}$ sample. After incubation at $37^{\circ} \mathrm{C}$ for $60 \mathrm{~min}, 1.0 \mathrm{ml} 5.0 \%$ trichloroacetic acid was added. The mixture was then centrifuged at 3000 r.p.m. for $10 \mathrm{~min}$ and filtered through Whatman no. 50 paper, after which the $A_{280}$ was measured. Control assays were done with incubation mixtures to which CAP was added just before the addition of trichloroacetic acid.

Cysteine proteinase inhibitory activity was assayed by measuring the inhibition of papain activity, as reported previously (Järvinen, 1976; Tsushima \& Hopsu-Havu, 1989). The sample $(0.1 \mathrm{ml})$ and $0.1 \mathrm{ml}$ of a $1.5 \mu \mathrm{g} \mathrm{ml}^{-1}$ papain solution were mixed with $0.1 \mathrm{ml} \quad 0.2 \mathrm{M}$ Tris $/ \mathrm{HCl}$ buffer ( $\mathrm{pH} \mathrm{8.0)}$ containing $8 \mathrm{mM}$ EDTA and $4 \mathrm{mM}$ dithiothreitol. After preincubation for $10 \mathrm{~min}$ at room temperature, $0 \cdot 1 \mathrm{ml} 5 \mathrm{mM}$ BANA was added, followed after another $30 \mathrm{~min}$ by $0.4 \mathrm{ml}$ p-dimethylaminobenzaldehyde. The $A_{450}$ was read $30 \mathrm{~min}$ later. Protein concentrations were determined by the Lowry method, with bovine serum albumin as the standard.

Electrophoresis. SDS-PAGE was performed according to the method of Laemmli (1970). Gels were stained with Coomassie Brilliant Blue R 250.
Interaction of CAP with human epidermal cystatin A. Twentyfive microlitres of $0.13 \mu \mathrm{M}$ CAP diluted with $0.1 \mathrm{M}$ sodium acetate buffer ( $\mathrm{pH} \mathrm{4.0)}$ was prewarmed with $25 \mu$ l of the same buffer at $37^{\circ} \mathrm{C}$ for $5 \mathrm{~min}$, and then mixed with $25 \mu \mathrm{l} 1.3 \mu \mathrm{M}$ human epidermal cystatin $\mathrm{A}$ and incubated at $37^{\circ} \mathrm{C}$ for various times. The reaction was stopped by acidifying to $\mathrm{pH} 2 \cdot 0$ with $10 \%(\mathrm{w} / \mathrm{v})$ trifluoroacetic acid (TFA:Pierce), then the incubated sample was applied to a reverse-phase HPLC column $(2.1 \times 150 \mathrm{~mm})$ that had been equilibrated with $0.1 \%$ TFA. HPLC was performed using a linear gradient of $0-50 \%$ acetonitrile (Nacalai Tesque, Kyoto, Japan) in $0.1 \%$ TFA for 60 min at a flow rate of $0.3 \mathrm{ml} \mathrm{min}^{-1}$. The peak fractions monitored by $A_{214}$ were collected and used as sequential samples. Pepstatin $(2 \mu \mathrm{M})$ treated samples were also applied to the HPLC column.

Sequence analysis. The $\mathrm{NH}_{2}$-terminal amino acid sequence of the digestion products of human epidermal cystatin $A$ was determined by automated sequence analysis with an Applied Biosystems 477 A protein sequencer.

\section{RESULTS}

\section{Purification of CAP and human epidermal cystatin A}

CAP was purified from C. albicans IFO 1060 culture medium containing bovine serum albumin. Its molecular mass was $42 \mathrm{kDa}$ on SDS-PAGE (Fig. 1a). When $2 \mu \mathrm{M}$ pepstatin was added to CAP at $\mathrm{pH} 4 \cdot 0$, its activity was completely inhibited (data not shown). Phenylmethylsulfonyl fluoride $(4 \mathrm{mM})$ and EDTA $(10 \mathrm{mM})$ had no inhibitory effect upon CAP. CAP activity was lost following dialysis against $10 \mathrm{mM}$ sodium phosphate buffer ( $\mathrm{pH} 7 \cdot 5$ ) at $4{ }^{\circ} \mathrm{C}$ overnight. These results confirmed that this purified enzyme is identical with the enzyme already characterized as CAP.

Human epidermal cystatin A was purified from skin scrapings. From $6.7 \mathrm{~g}$ scrapings, $1.54 \mathrm{mg}$ purified inhibitor was obtained. It migrated as a single distinct band with a molecular mass of $12 \mathrm{kDa}$ on SDS-PAGE (Fig. 1b). This was the same molecular mass as previously reported for cystatin A (Barrett $e t$ al., 1986). The sequence of the first $30 \mathrm{~N}$-terminal amino acid residues of purified epidermal cystatin A was identical with that previously reported for epidermal cystatin A (Takeda et al., 1989).

\section{Interaction of CAP with human epidermal cystatin A}

CAP was unaffected by human epidermal cystatin A, even when incubation was continued for $12 \mathrm{~h}$ (data not shown). In contrast, the inhibitory activity of cystatin A decreased according to the duration of incubation with CAP (Fig. 2). After $12 \mathrm{~h}$ incubation, $90 \%$ of the original activity was lost. The possibility of inactivation by acid denaturation was ruled out, because cystatin $\mathrm{A}$ is a stable protein within the $\mathrm{pH}$ range 2-12 (Barrett $e$ t al., 1986). The activity of human epidermal cystatin $A$ was not changed when pepstatin was added to a mixture of cystatin $A$ and CAP.

To further investigate the digestion of cystatin $A$, we used reverse-phase HPLC and sequenced each of the digested peptides. The main cleavage patterns found after $30 \mathrm{~min}$ and $12 \mathrm{~h}$ incubation with CAP are shown in Fig. 3(a, b). 
(a)

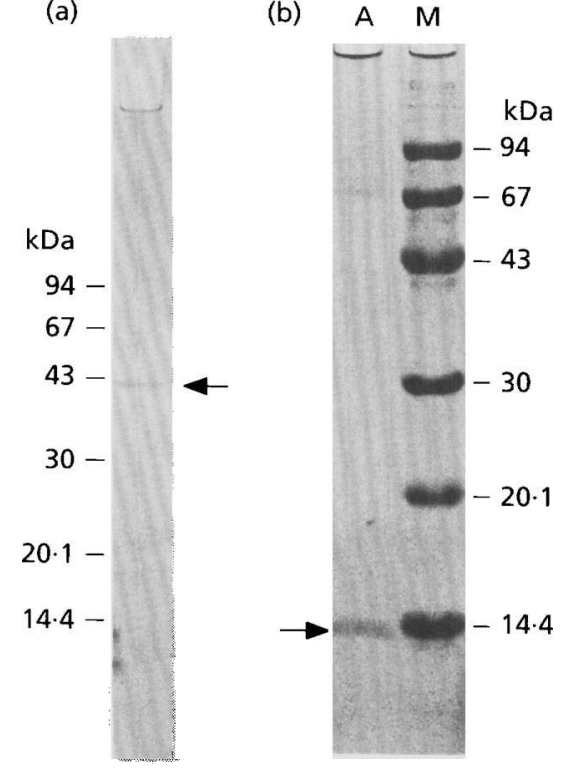

Fig. 1. SDS-PAGE of purified CAP (a) and purified human epidermal cystatin $A$ (b) under reducing conditions. (a) The arrow indicates the band of purified CAP with a molecular mass of $42 \mathrm{kDa}$. (b) Lane $A$, purified human epidermal cystatin $A$ (arrow). Lane $M$, molecular mass standards. From the top: phosphorylase $b(94 \mathrm{kDa})$, bovine serum albumin $(67 \mathrm{kDa})$, carbonic anhydrase $(30 \mathrm{kDa})$, soybean trypsin inhibitor $(20 \cdot 1 \mathrm{kDa})$, and $\alpha$-lactalbumin (14.4 kDa).

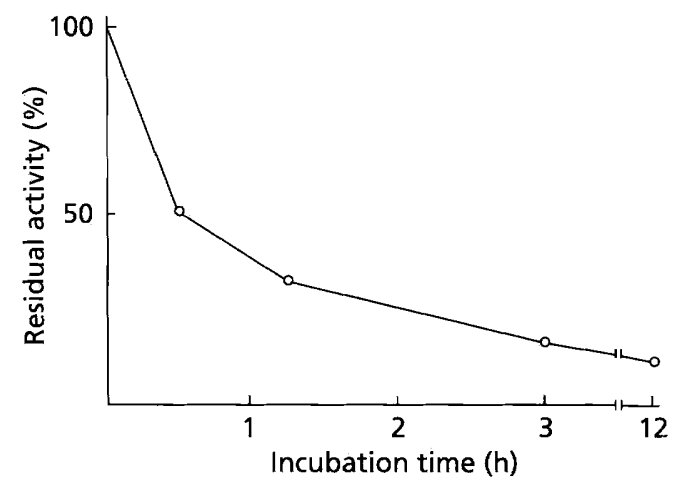

Fig. 2. Changes of human epidermal cystatin A activity after incubation with CAP for up to $12 \mathrm{~h}$. Twenty-five microlitres $0.13 \mu \mathrm{M}$ CAP was preincubated with $25 \mu \mathrm{l} 0.1 \mathrm{M}$ sodium acetate buffer, $\mathrm{pH} 4.0$, and then reacted with $25 \mu \mathrm{l} 1.3 \mu \mathrm{M}$ human epidermal cystatin $A$ for $30 \mathrm{~min}, 75 \mathrm{~min}, 3 \mathrm{~h}$ and $12 \mathrm{~h}$ at $37^{\circ} \mathrm{C}$. After the reaction, $50 \mu \mathrm{l} 0.5 \mathrm{M}$ Tris/ $/ \mathrm{HCl}$ buffer $(\mathrm{pH} \mathrm{8.0)}$ ) was added, and then papain-inhibitory activity was assayed. The cystatin activity in the absence of CAP was taken as $100 \%$.

None of the digested peptides had any papain-inhibitory activity. On adding $2 \mu \mathrm{M}$ pepstatin, cystatin A digestion was completely inhibited (data not shown). The cleavage sites are summarized in Fig. 4. The most common sites were QE, EA, DK, EE, KT, QY, QV, YY, KV, KY, $\mathrm{DL}, \mathrm{YQ}$ and $\mathrm{KN}$. After incubation for $12 \mathrm{~h}$, additional cleavage sites appeared. Two residues at positions 19 and
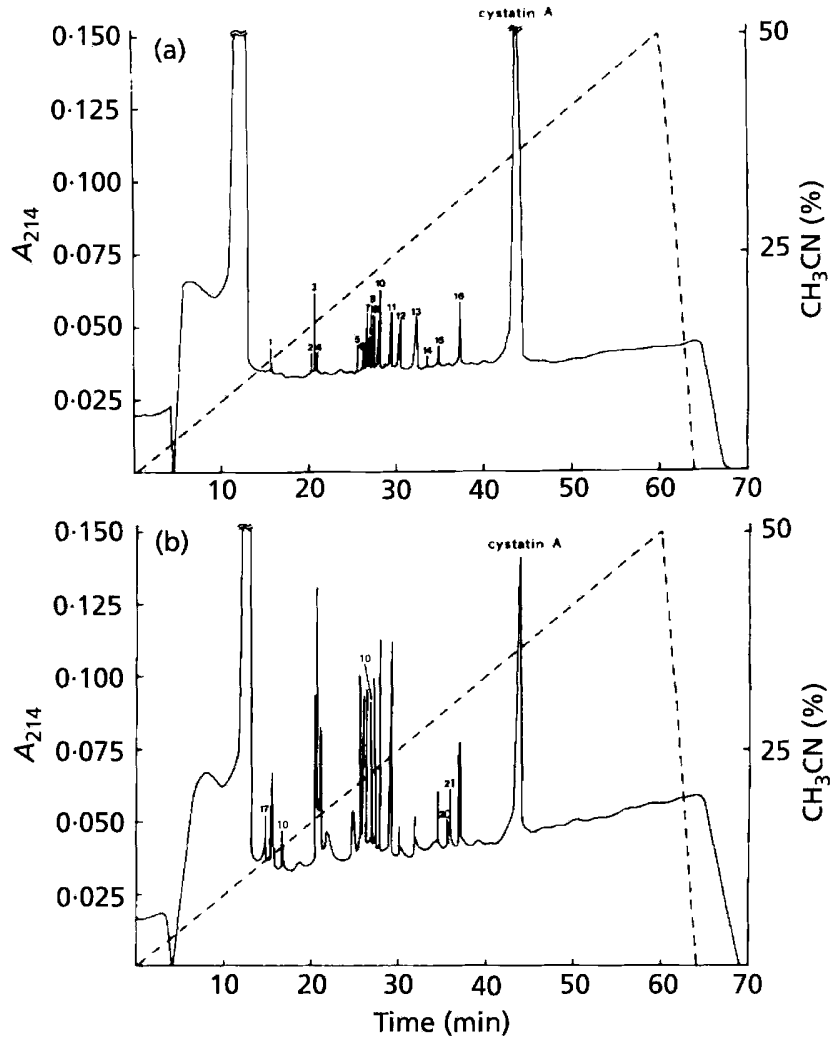

Fig. 3. Reverse-phase HPLC profiles of cleavage peptides obtained from human epidermal cystatin $A$ after incubation with CAP. (a) After 30 min incubation; (b) after $12 \mathrm{~h}$ incubation. One hundred microlitres of the reaction mixture was applied to the reverse-phase HPLC column. The peaks obtained after $30 \mathrm{~min}$ incubation are designated $1-16$ and the new peaks appearing after $12 \mathrm{~h}$ incubation are designated 17-21. Their sequential positions are indicated in Fig. 4. - - , $A_{214} ;---$ $\mathrm{CH}_{3} \mathrm{CN}$ gradient.

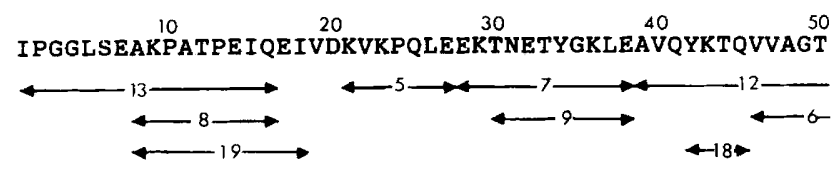

NYY I KVRAGDNKYMHLKVFKSLPGQNEDLVLTGYQVDKNKDDELTGF

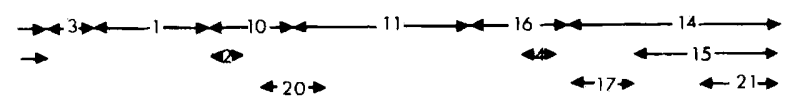

Fig. 4. Cleavage of human epidermal cystatin A by CAP. The double-headed arrows indicate the regions of the cleavage peptides. The top and middle lines show the cleavage patterns after $30 \mathrm{~min}$ incubation. The bottom line shows new cleavage patterns appearing after $12 \mathrm{~h}$ incubation.

20 were not detected in a search of the digested peptides (Fig. 4). It seems that they were in peptide peaks that were missed by HPLC, since we detected these residues in the sequence of the native inhibitor (data not shown). These 
results show that the inhibitory activity of human epidermal cystatin $\mathrm{A}$ is lost due to cleavage by CAP.

\section{DISCUSSION}

Many researchers have suggested CAP as a possible virulence factor in C. albicans infection (Germaine $e t$ al., 1978; Rüchel, 1981; MacDonald \& Odds, 1983; Odds, 1985; Kwon-Chung et al., 1985; Rüchel et al., 1985; Ghannoum \& Elteen, 1986; Borg \& Rüchel, 1988). With regard to $C$. albicans infection of human skin, it seemed important to determine whether epidermal cystatin A, which may have a protective function against various pathogens (see Introduction), could be degraded and inactivated by CAP.

CAP is an aspartic proteinase, like pepsin, cathepsin D and cathepsin E. In this study, it was shown that CAP can degrade human epidermal cystatin A in vitro. CAP was shown to have endopeptidase activity, but its cleavage patterns were different from (and broader than) those reported for human cathepsin D (Lenarcic et al., 1988).

Matsuda (1986), studying the growth of C. albicans in medium supplemented with human stratum corneum, suggested that $C$. albicans is able to adjust the environmental $\mathrm{pH}$ to around 4 (which is the optimum $\mathrm{pH}$ of CAP) for its growth by obtaining nutrients from human stratum corneum through digestion by the released CAP. Ray \& Payne (1988) also speculated that actively growing Candida cells produce a circumjacent acidic milieu conducive to CAP activity. In cutaneous $C$. albicans infectious lesions, epidermal cystatin A might be cleaved and inactivated by CAP.

\section{Conclusions}

The results of this study suggest that CAP may function as a virulence factor by altering the proteolytic balance in the skin. We speculate that the degradation of epidermal cystatin A by CAP may induce an imbalance of cysteine proteinase and its inhibitor, and this imbalance may promote infection. However, the existence and physiological roles of $C$. albicans cysteine proteinase remain to be studied.

\section{ACKNOWLEDGEMENT}

We thank K. Higashiyama for assisting with the amino acid sequence analysis.

\section{REFERENCES}

Ahearn, D. G. (1978). Medically important yeasts. Ann Rev Microbiol 32, 59-68.

Anastasi, A., Brown, H. A., Kembhavi, A., Nicklin, J. H., Sayers, C. A., Sunter, D. C. \& Barrett, A. J. (1983). Cystatin, a protein inhibitor of cysteine proteinases. Improved purification from egg white, characterization, and detection in chicken serum. Biochem J 211, 129-138.

Anson, M. L. (1938). The estimation of pepsin, trypsin, papain, and cathepsin with hemoglobin. J Gen Pbysiol 22, 79-85.

Barrett, A. J., Fritz, H., Grubb, A., Isemura, S., Järvinen, M., Katunuma, N., Machleidt, W., Müller-Esterl, W., Sasaki, M. \&
Turk, V. (1983). Nomenclature and classification of the proteins homologous with cysteine proteinase inhibitor chicken cystatin. Biochem J 236, 312.

Barrett, A. J., Rawlings, N. D., Davies, M. E., Machleidt, W., Salvesen, G. \& Turk, V. (1986). Cystein proteinase inhibitors of the cystatin superfamily. In Proteinase Inbibitors, pp. 515-569. Edited by A. J. Barrett \& G. Salvesen. Amsterdam: Elsevier.

Björck, L., Akesson, P., Bohnus, H., Tronjnar, T., Abrahamson, M., Olafsson, T. \& Grubb, A. (1989). Bacterial growth blocked by a synthetic peptide based on the structure of a human proteinase inhibitor. Nature 337, 385-386.

Björck, L., Grubb, A. \& Kjellen, L. (1990). Cystatin C, a human proteinase inhibitor, blocks replication of herpes simplex virus. J Virol 64, 941-943.

Borg, M. \& Rüchel, R. (1988). Expression of extracellular proteinase by proteolytic Candida spp. during experimental infection of oral mucosa. Infect Immun 56, 626-631.

Germaine, G., Tellefson, L. M. \& Johnson, G. L. (1978). Proteolytic activity of Candida albicans: action of human salivary proteins. Infect Immun 22, 861-866.

Ghannoum, M. \& Elteen, K. A. (1986). Correlative relationship between proteinase production, adherence and pathogenicity of various strains of Candida albicans. J Med Vet Mycol 24, 407-413.

Hattori, M., Yoshiura, K., Negi, M. \& Ogawa, H. (1981). Keratinolytic proteinase produced by Candida albicans. Sabouraudia 22, 175-183.

Hopsu-Havu, V. K., Joronen, I. A., Järvinen, M. \& Rinne, A. (1983). Cysteine proteinase inhibitors in psoriatic epidermis. Arch Dermatol Res 275, 305-309.

Järvinen, M. (1976). Purification and properties of two protease inhibitors from rat skin inhibiting papain and other $\mathrm{SH}$-proteases. Acta Chem Scand B 30, 933-940.

Kaminishi, H., Hagihara, Y., Hayashi, S. \& Cho, T. (1986). Isolation and characteristics of collagenolytic enzyme produced by Candida albicans. Infect Immun 53, 312-316.

Kaminishi, H., Hagihara, Y., Tanaka, M. \& Cho, T. (1988). Degradation of bovine achilles tendon collagen by Candida albicans proteinase. J Med Vet Mycol 26, 315-318.

Katunuma, N. (1989). Possible regulatory mechanisms of intracellular protein catabolism through lysosome. In Intracellular Proteolysis, pp. 3-23. Edited by N. Katunuma \& E. Kominami. Tokyo: Japan Science Press.

Korant, B. D., Brzin, J. \& Turk, V. (1985). Cystatin, a protein inhibitor of cysteine proteinases alters viral protein cleavage in infected human cells. Biochem Biopbys Res Commun 127, 1072-1076.

Kwon-Chung, K. J., Lehman, D., Good, C. \& Magee, P. T. (1985). Genetic evidence for role of extracellular proteinase in virulence of Candida albicans. Infect Immun 49, 571-575.

Laemmli, U. K. (1970). Cleavage of structural proteins during the assembly of the head of bacteriophage T4. Nature 277, 680-685.

Lenarcic, B., Kos, J., Dolenc, I., Lucovnik, P., Krizaj, I. \& Turk, V. (1988). Cathepsin D inactivates cysteine proteinase inhibitors cystatins. Biochem Biopbys Res Commun 154, 765-772.

MacDonald, F. \& Odds, F. C. (1983). Virulence for mice of a proteinase-secreting strain of Candida albicans and a proteinasedeficient mutant. J Gen Microbiol 129, 431-438.

Matsuda, K. (1986). Influence of nitrogen source, $\mathrm{pH}$ of media and Candida albicans-producing proteinase (CAPP) (= Keratinolytic proteinase; KPase) on the growth of C. albicans. Jpn J Med Mycol 27, 100-106 (in Japanese).

Odds, F. C. (1985). Candida albicans proteinase as a virulence factor 
in the pathogenesis of Candida infections. Zentralbl Bakteriol Mikrobiol Hyg Abt I 260, 539-542.

Ray, T. L. \& Payne, C. D. (1988). Scanning electron microscopy of epidermal adherence and cavitation in murine candidiasis: a role for Candida acid proteinase. Infect Immun 56, 1942-1949.

Ray, T. L. \& Payne, C.D. (1991). Degradation of basement membrane matrix proteins laminin, fibronectin, and type IV collagen by Candida acid proteinase. J Invest Dermatol 96, 606 A.

Remold, H., Fasold, H. \& Staib, F. (1968). Purification and characterization of a proteolytic enzyme from Candida albicans. Biochim Biophys Acta 167, 399-406.

Rüchel, R. (1981). Properties of a purified proteinase from the yeast Candida albicans. Biochim Biophys Acta 659, 99-113.

Rüchel, R. (1986). Cleavage of immunoglobulins by pathogenic yeasts of the genus Candida. Microbiol Sci 3, 316-319.

Rüchel, R., Boning, B. \& Jahn, E. (1985). Identification and partial characterization of two proteinases from the cell envelope of Candida albicans blastospores. Zentralbl Bakteriol Mikrobiol Hyg Abt I 260, 523-538,

Takeda, A., Kaji, H., Nakaya, K., Nakamura, Y. \& Samejima, T. (1989). Comparative studies on the primary structure of human cystatin As from epidermis, liver, spleen, and leukocytes. I Biochem 105, 986-991.

Tsushima, H. \& Hopsu-Havu, V. K. (1989). Cysteine proteinase inhibitors in human squamous cell carcinoma. Acta Histochem $\mathbf{8 5}$, 23-28.

Tsushima, H., Ueki, A., Mine, H., Nakajima, N., Sumi, H. \& HopsuHavu, V. K. (1992). Purification and characterization of a cystatintype cysteine proteinase inhibitor in the human hair shaft. Arch Dermatol Res 284, 380-385.

Received 15 March 1993; revised 4 June 1993; accepted 16 June 1993. 